\title{
Coral reefs are critical for our food supply, tourism, and ocean health. We can protect them from climate change
}

\author{
Hanny E. Rivera ${ }^{1, *}$, Andrea N. Chan ${ }^{2, \dagger}$, and Victoria Luu ${ }^{3}$ \\ Edited by Alexandra Churikova and Anthony Tabet
}

\section{HIGHLIGHTS}

- Coral reefs provide ecosystem services worth $\$ 11$ trillion dollars annually by protecting coasts, sustaining fisheries, generating tourism, and creating jobs across the tropics.

- Ocean warming is the most widespread and immediate threat to coral reefs globally, followed by disease, and local stressors.

- Management efforts help address local stressors, however, the root cause of global coral decline - increasing temperatures caused by greenhouse gas emissions - must be addressed to ensure the survival of the ocean's most diverse habitats through the 21st century.

- International climate agreements that aim to continually reduce emissions are our best hope for the survival of reefs.

As many as 1 billion people across the planet depend on coral reefs for food, coastal protection, cultural practices, and income [1,2]. Corals, the animals that create these immensely biodiverse habitats, are particularly vulnerable to climate change and inadequately protected. Increasing ocean temperatures leave corals starved as they lose their primary source of food: the photosynthetic algae that live within their tissue. Ocean warming has been impacting coral reefs around the globe for decades, with the latest 2014-2016 heat stress event affecting more than $75 \%$ of the world's corals $[3,4]$. Here, we discuss the benefits humans derive from healthy reefs, the threats corals face, and review current policies and management efforts. We also

\footnotetext{
${ }^{1}$ Department of Biology, Boston University, Boston, MA

${ }^{2}$ Department of Biology, Pennsylvania State University, University Park, PA

${ }^{3}$ Department of Geosciences, Princeton University, Princeton, NJ

*Email: hrivera28@gmail.com
}

${ }^{\dagger}$ Present Address: ECS Federal, LLC in support of NOAA National Marine Fisheries Service, Office of Science and Technology, Silver Spring, MD, United States

The authors declare no conflict of interest. The views expressed are those of the authors, and do not necessarily represent findings or policy of any government agency.

(C) 2020 The Author(s) identify management and policy gaps in preserving coral habitats. The gain and urgency of protecting coral reefs is evident from their vast economic and ecological value. Management and restoration efforts are growing across the globe, and many of these have been influential in mitigating local stressors to reefs such as overfishing, nutrient inputs, and water quality. However, the current trajectory of ocean temperatures requires sweeping global efforts to reduce greenhouse gas emissions in order to effectively safeguard the future of coral reefs. The U.S. should stand as a world leader in addressing climate change and in preserving one of the planet's most valuable ecosystems.

C oral reefs are one of our planet's most biodiverse and economically valuable ecosystems [5], yet they have been declining worldwide due to warming ocean temperatures and other stressors [6]. Many major tropical cities are adjacent to coral reef environments (Figure $1 \mathrm{~A}$ ), with nearly 1 billion people worldwide residing in areas influenced or sustained by coral reefs $[1,2]$. Coral reefs provide a myriad of ecosystem services that benefit our economies, our shorelines, as well as our plates and medicine cabinets (Figure 2). Throughout, we discuss the valuable benefits provided by corals, explain the stressors harming coral reef ecosystems across global and local scales, review management and conservation efforts, and identify gaps in current policies.

Why corals matter: A wealth of ecosystem services

Coral reefs are dynamic, vibrant ecosystems, formed by over 800 different species of corals. Corals are animals, closely related to anemones and jellyfish, although considering them rocks or plants would not be entirely off base. Their tripartite nature stems from their ability to create the limestone skeleton in which they live, and from the single-celled algae (marine plants) that live inside their tissues in a mutualistic symbiosis (Figure 3A). These algae provide corals with the vast majority of their energetic needs, by providing sugars they produce via photosynthesis to their coral hosts. In addition, corals also harbor a diverse bacterial flora that contributes to their overall health [7], much like the gut microbiome does in humans [8]. These associations allow corals to thrive and build reefs large enough to be seen from space, such as the Great Barrier Reef or the Florida Reef Tract (Figure 1B, 1C). 

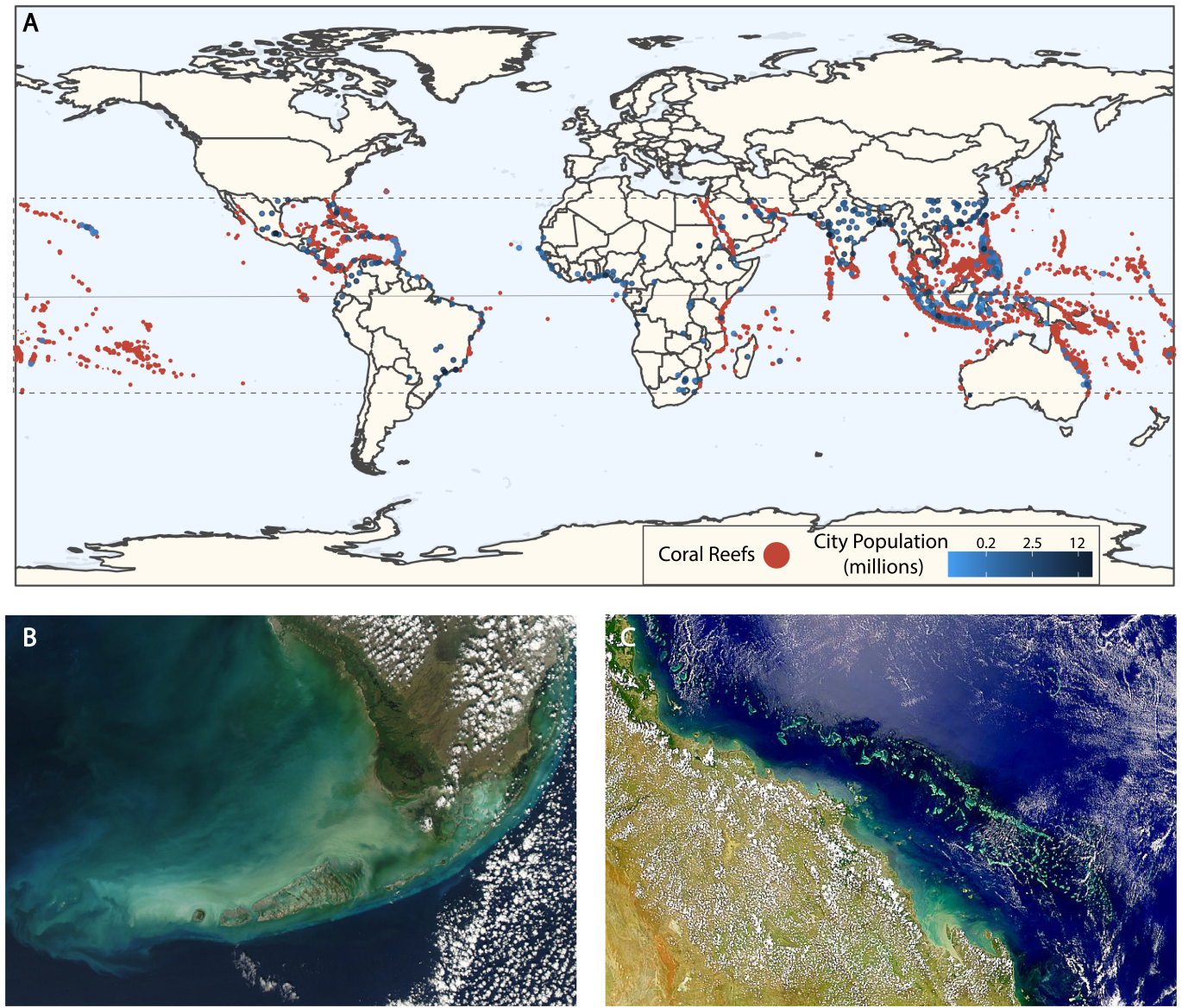

Figure 1: Reefs around the world. (A) Global distribution of coral reefs and nearby cities. Coral is shown in red. Cities are shown as circles shaded in increasing intensity of blue based on population size. Cities depicted are within $30^{\circ} \mathrm{N}$ or $\mathrm{S}$ latitude (dashed box), with the exception of cities in Japan, Bermuda, and Perth, Australia. Cities shown are capitals or administrative seats of government, or cities with a population over 800,000. Equator is shown as a gray horizontal line. (B) The Florida Barrier Reef as seen from space. (C) The Great Barrier Reef, Australia as seen from space. Images from B and C from NASA Image Gallery.

Coastal Protection: These massive reefs structures can function as seawalls against storms, hurricanes, and sea level rise by protecting coasts from waves and surge [9]. In fact, coral reefs provide the equivalent of $\$ 94$ million in coastal protection to the U.S. each year [10]. During severe storms, like category 5 hurricanes, that value increases to $\$ 272$ billion [10]. Worldwide, the total value of coastal protection provided by reefs is estimated at over $\$ 4$ billion in averted damages during usual storms [10]. For more extreme events such as one-in-25-year or one-in-a-100-year level storms, corals can prevent $\$ 36$ billion to $\$ 130$ billion dollars' worth of damages, respectively [10]. For comparison, the Port of Miami and Port Everglades (Ft. Lauderdale, FL) collectively represent over $3 \%$ of all U.S. seaport trade and are worth over $\$ 50$ billion dollars each year; while the Miami International Airport comprises over $5 \%$ of U.S. airport trade, worth nearly $\$ 60$ billion per year [11]. Corals can provide equivalent amounts of value during mild storms and much more value during severe storms. Coastal protection by coral reefs not only benefits immediately adjacent cities and residents, but can also prevent downstream economic impacts to trade and commerce. In addition, the presence of coral reefs is often used to define maritime boundaries and jurisdictions (see section on UN Convention on the Law of the Sea), such that deterioration and loss of coral reef habitat can lead to loss of jurisdiction over marine territories.

Biodiversity and Natural Products: The reef structures created by corals provide habitat for thousands of marine species, in a manner that is highly disproportionate to their total area. While comprising only a small fraction of seafloor $(0.2 \%)$ [12], coral reefs are home to an estimated 830,000 species of organisms [13]. The number of species living per unit area on coral reefs is one of the highest on the planet, with biodiversity that rivals rainforests.

This biodiversity is crucial for the health our oceans, and it can also be harnessed for natural product and drug development. For instance, the antiviral drug Vira-A, which is used to treat herpes simplex infections, as well as $A Z T$, which is used to treat $\mathrm{HIV}$, were derived from a compound (Ara-A) isolated from a Caribbean sponge that lives on coral reefs [14]. Another compound (Ara-C) was isolated from the same sponge and developed into the anti-cancer medication Cytarabine [14]. The drug Ziconotide for the treatment of chronic pain was isolated from cone snails found on coral reefs [15]. In addition, several new antibiotic compounds effective against 
antibiotic-resistance bacteria have been isolated from soft corals that live in coral reefs [16]. The skeletons of hard corals can even be used as bone regeneration materials for humans [17] Overall, the oceans represent a highly unexplored source of products for human medicine. The drug discovery potential in marine environments, and coral reefs in particular, should be considered an invaluable resource $[18,19]$.

Fisheries and Tourism: The biodiversity of corals reefs also includes fish and seafood species that form part of a 143 billion dollar global fisheries trade industry, such as groupers, lobsters, and snappers [20]. In the U.S., recreational fisheries on coral reefs are worth over $\$ 100$ million each year. In addition, nearly half of all U.S. fisheries depend on healthy coral reefs ecosystems for sustainable stocks [21]. Excessive fishing on reefs can cause considerable damage and threaten the stability of the ecosystem (see fishing pressure section below). As such, coral reef fisheries benefit from strong management plans that limit the risk of overfishing important species.

Coral reefs also form the foundation of many tourism industries in coastal areas across the globe. In Australia, the Great Barrier Reef received over 26 million visitors in 2016, and tourism to the Queensaland area generates around $\$ 6.4$ billion (AUD) annually [22]. In the U.S., reef-based tourism in the states of Hawai'i and Florida alone are estimated at over $\$ 2$ billion dollars annually [23]; and at nearly $\$ 240$ million in Puerto Rico [21]. ${ }^{1}$

\section{What's killing all the corals: Global and local threats to reefs}

Despite their vast ecological, economical, and pharmaceutical importance, coral reefs are one of the planet's most rapidly degrading ecosystems [6]. On a global scale, corals are most severely impacted by increasing temperatures, coral diseases, and declining $\mathrm{pH}$ levels. At regional and local scales, stressors such as overfishing, run-off from land, and coastal development lead to coral mortality and reef degradation [24]. We discuss the causes, effects, and prevalence of different stressors below. While we have organized this section into global and local stressors, reefs are complex ecosystems and are often subjected to multiple stressors simultaneously. It should also be noted that this is not a comprehensive list. For instance, we do not discuss light and noise pollution, ship groundings, invasive species, or tourism pressure. We have focused on the stressors that we consider the most pressing to address given the magnitude of their impact.

\section{Global Stressors}

Temperature: Corals can suffer severe stress if water temperatures rise by just $1^{\circ} \mathrm{C}$ above their usual summer maximum [25]. While this change in temperature may seem trivial at first, consider the impacts of a fever on human health, where only a $1-2^{\circ} \mathrm{C}$ increase can quickly become life threatening. At higher temperatures, corals lose the

\footnotetext{
[21]
}

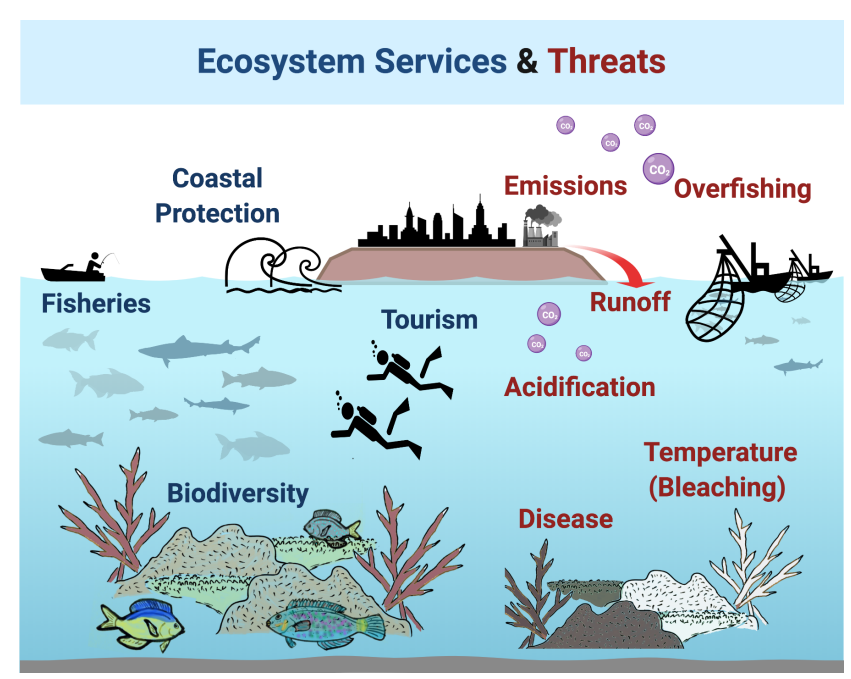

Figure 2: Coral reef ecosystem services (blue) and threats (red). Reefs offer valuable services to humans. Unfortunately, corals are impacted by multiple threats, many of which act to compound each other. Image was created on biorender.com. Icon credits to Lluisa Iborra (skyline), Ifki Rianto (small fishing boat and fisherman), Ruliani (wave), Nikita Kozin (diver), and Luis Prado (large fishing boats), all available from The Noun Project. Reef and associated fish are original artwork by author H.E.R.

symbiotic algae that live inside their tissues, and which provide the coral with the majority of their daily food requirements $[25,26]$ (Figure $3 \mathrm{~A})$. This process is called 'bleaching,' as the symbionts are also the main source of color in coral tissue (Figure 3B). Bleaching is often fatal to the coral animal, as they can starve to death without their symbionts. If temperatures return to normal within a few days or weeks, the coral can re-establish their community of symbionts and may survive; but this time window is becoming more elusive as heat stress events are becoming both more prolonged and more severe [27].

Since the 1980s, episodes of bleaching have reached reefs around the world, and even iconic and well-protected areas, like the Great Barrier Reef have lost up to $50 \%$ of their live coral [6]. Such bleaching events have increased in both frequency and intensity over the last two decades, and it is projected that by 2050 almost all reefs will experience bleaching level temperatures on an annual basis $[27,28]$. The most recent global bleaching event (between 2014-2016) caused devastation across the globe [3]. For instance, this event caused $100 \%$ bleaching and nearly $95 \%$ coral mortality on Jarvis Island, a U.S. territory in the central Pacific [29]. This island had previously been rated as the healthiest and most robust coral ecosystem on the planet [30], and lacks any other sources of coral stress, underscoring the pervasive impact climate change can have on even the most remote and pristine ecosystems. The Great Barrier Reef in particular, has continued to experience bleaching events every year since 2014 , and is seeing its most widespread bleaching event this year [31]. On a smaller scale, other stressors can also prompt a bleaching response in corals, including cold temperature, pollution, high UV, and pathogens [16]. However, heat-induced 
mass bleaching remains the primary cause of coral decline on a global scale $[4,28,32,33]$. These declines emphasize the desperate need to curtail the carbon emissions that are responsible for increasing ocean temperatures.

Disease: Corals have also been affected by disease outbreaks, especially in the Atlantic/Caribbean, where they have been one of the main sources of decline from the mid 1970's to today [34]. In the late 1970's, an outbreak of white band disease decimated the three major Caribbean coral species (Acropora cervicornis, palmata, and prolifera) that were the dominant reef builders in the region [35]. In 2014, a new disease, now called Stony Coral Tissue Loss Disease (SCTLD), began in Miami-Dade County, and has since spread throughout the Caribbean [36]. The disease impacts more species than any other known coral diseases, and also kills corals more quickly [36]. In Florida alone, more than $30 \%$ of corals have died from the disease over the last few years [36]. Despite much investigation, scientists have yet to isolate the pathogen that causes the disease.

Disease prevalence in corals has also been increasing over time and is sometimes exacerbated by increased temperatures [37]. Combined, disease and bleaching are major causes of coral mortality, and both are predicted to worsen as climate change progresses [33,37]. Diseases can also be triggered by local stressors such as coastal human inputs. For instance, in Guam, prevalence of white syndrome was linked to increased nitrogen from sewage outfalls [38]. In Florida, the outbreak of SCTLD also coincided with the dredging of Port Miami, which led to substantial sedimentation and coral mortality [39] [40]. An overall increase in nutrients has also been linked to higher disease prevalence in the both field and experimental studies [41]. Given these synergies, outbreaks of coral diseases are expected to increase [42]. Management efforts that aim to limit sources of coral disease should be high priority especially in the Atlantic/Caribbean, where they have already caused substantial decline.

Ocean acidification (declining ocean pH): In addition to warming our planet, carbon dioxide emitted into the atmosphere dissolves into our oceans, triggering chemical reactions that increase the acidity of the water (lower the $\mathrm{pH}$ level) [43]. Some studies indicate that $\mathrm{pH}$ levels in reef water are declining more rapidly than in the open ocean [44]. At lower $\mathrm{pH}$, the process that corals use to build their skeletons (calcification) and which creates the reef structure requires more energy, meaning coral growth slows and they build less reef [45]. The chemical dissolution of older reef structures, as well as erosion of live corals by live organisms, like encrusting mussels or worms, is also easier at lower $\mathrm{pH}[46,47]$.

Ocean acidification also negatively impacts the many shell-building organisms that reside on reefs, such as mussels, clams, urchins, and other calcifying organisms [48]. Even fish growth and metabolism can be impacted under low $\mathrm{pH}$, especially during larval stages [49] In addition, $\mathrm{pH}$ often interacts negatively with warmer temperatures, hindering growth and survival of corals [50]. As with mitigating the effects of warming, addressing the root cause - rising $\mathrm{CO} 2$ levels - is the best course of action to prevent further damage.

\section{Local Stressors}

Coastal Development and Nutrient Enrichment: Coastal development can generate sedimentation from poor-land use practices and new development, or nutrient run-off from agriculture and wastewater discharge. The construction of new resorts may involve overwater bungalows, built directly on reef structures, or the creation of artificial beaches that change coastline dynamics and increase sedimentation to nearby reefs. The expansion of ports to accommodate cruise liners or large container ships, often requires dredging of the surrounding reef flats in smaller tropical islands [51,52], or even larger cities like Miami [40]. On a more dramatic scale, territorial conflicts in Spratly Islands in the South China Sea, have led to land reclamation techniques by China in which reefs are filled to create land that can be claimed [53]. Such efforts destroyed an estimated 6 square miles (3,000 football fields) of coral reef habitat in 2015 [54]. Coastal development represents a severe a direct physical risk to coral reef survival. The environmental impacts of development projects should be thoroughly assessed by independent parties prior to permitting to help alleviate such pressures.

Nutrient influx to reefs is primarily driven by human activity. Coastal development, sewage and water treatment effluents, agricultural runoff, and discharges from shipping can all increase nutrient levels on reefs. Macroalgae (different from the microalgae that live inside coral tissues) compete with corals for space on reef environments [55]. Normally, macroalgal growth is limited by nutrient availability, but with an influx of nutrients algae can grow more quickly and begin to grow over the coral [55]. This often results in a shift from a coral-dominated reef to an algal-dominated ecosystem [56] (Figure 3B). These patterns can also be exacerbated if there is overfishing of herbivorous fish, which help keep macroalgal populations in check (see Fishing Pressure).

Algal-dominated habitats quickly begin to lose fish species that relied on corals for shelter [56]. Algae can also trap sediments, leading to negative feedback loops that further stress the remaining corals [57]. Algal-dominated reefs lose their value as protective barriers to shorelines, as dead corals can no longer create additional reef structure. In addition, nitrogen and carbon inputs from land can alter the $\mathrm{pH}$ of coastal waters, exacerbating ocean acidification in those areas [58]. Policies that limit the environmental impact of coastal development projects and ensure that coastal infrastructure (e.g. sewage pipes and water treatment plants) is well-maintained can significantly limit continued damage to coral reefs locally.

Fishing Pressure: Corals rely on healthy populations of herbivorous fish and invertebrates to keep macroalgal populations from outcompeting them [59]. Overfishing of herbivores like parrotfish and rabbitfish can result in algal population spikes [60,61]. In 1990, Bermuda banned pot fishing, a practice that mainly impacted herbivorous fish 
species. As a result, populations of herbivores rebounded [62]. Other fishing practices like dynamite (also called blast fishing) or cyanide fishing can directly destroy reef habitats and kill coral reef organisms. While these methods are not practiced in the U.S., they still represent a significant threat to reefs in the Indo-Pacific, where many U.S. and international non-profits dedicate efforts to reef conservation. Dynamite and cyanide fishing are often practiced by smaller-scale fishermen, harvesting coral reef fish for the aquarium trade (most of which is sent to U.S.) or direct consumption. In Tanzania, for example, dynamite fishing was outlawed in the 1970s, but has continued essentially unchecked [63]. Cyanide fishing allows for the live capture of fish by temporarily anesthetizing them [64]. The concentrations of cyanide used to target the desired fish, however, can be quickly detrimental to coral reef organisms, such as smaller fish and invertebrates [64]. Efficient enforcement against both these practices in the Indo-Pacific would be a substantial relief to local coral reefs; as would limiting overfishing of herbivorous species across coral habitats.

\section{What's protected: U.S. policies addressing coral reefs}

Reducing human access to reefs can mitigate the impact of local stressors on corals - buying them time to become more tolerant of global stressors [65]. Marine Protected Areas (MPAs) are defined as: "[an] area of the marine environment that has been reserved by federal, state, territorial, tribal, or local laws or regulations to provide lasting protection for part or all of the natural and cultural resources therein" (Executive Order 13158, 2000). MPAs may differ in their level of restrictions depending on the conservation goals surrounding their designation. Two specific classes of MPAs are sanctuaries and monuments. The National Oceanic and Atmospheric Administration (NOAA) and Congress may both designate sanctuaries under the National Marine Sanctuaries Act (16 U.S.C. §§ 1431 et seq., 1972), while the President can establish marine national monuments under the Antiquities Act of 1906 (54 U.S.C. $\S \S 320301-320303,1906$ ). A number of MPAs include coral reef habitats within U.S. jurisdiction:

- Papahānaumokuākea National Marine Monument in the Northwestern Hawaiian Islands was established in 2006 and is the largest contiguous marine conservation area under U.S. jurisdiction (Proclamation 8031, 2006). A proclamation by President Obama expanded the monument to cover the entire U.S. exclusive economic zone west of 163 West Longitude, providing greater protection for the region's coral reefs (Proclamation 9478, 2016).

- Pacific Remote Islands Marine National Monument includes Wake, Baker, Howland, and Jarvis Islands, Johnston and Palmyra Atolls, and Kingman Reef. Protecting the high coral diversity and endemic coral species in these areas was a major justification for its establishment (Proclamation 8336, 2009).

- Florida Keys National Marine Sanctuary protects the

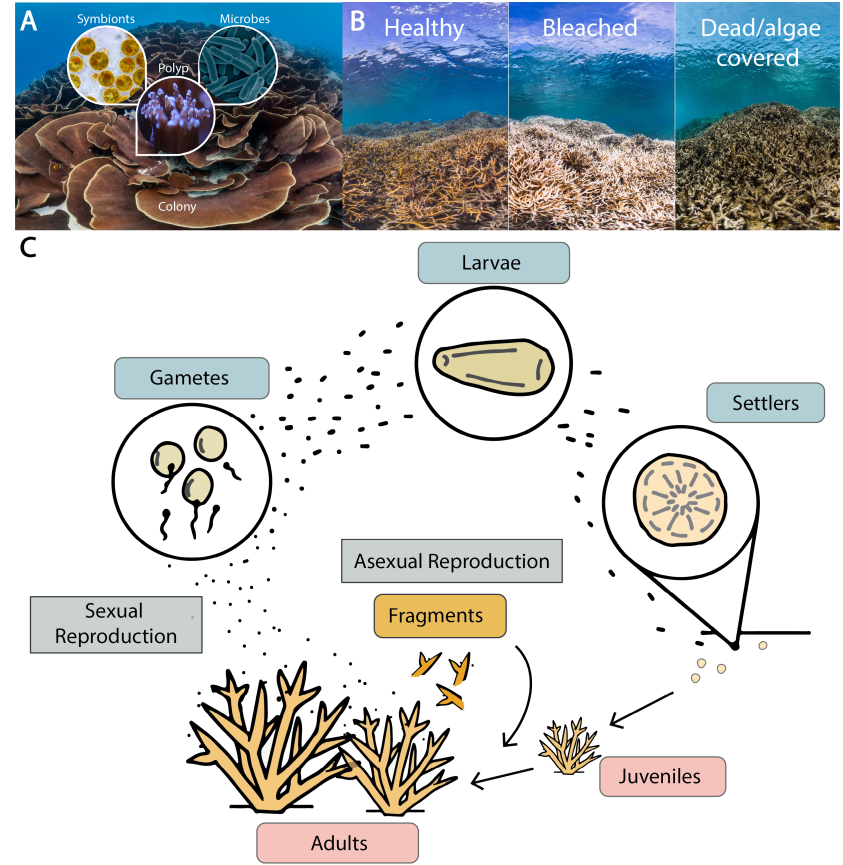

Figure 3: Overview of coral biology. (A) Coral symbiosis. Corals form massive reef structures made of calcium carbonate (limestone) as their skeleton. The live coral tissue is at the surface of this rock, where colonies of polyps (middle inset) cover the skeleton. Inside the polyps, single-celled algal symbionts (left inset) live in specialized tissues. In addition, a diverse microbial community (right inset) lives on and within corals. (B) Coral bleaching and algal overgrowth. A healthy reef (left) undergoes bleaching due to high temperatures (middle). The coral is unable to recover and dark brown macroalgae now grows over the dead coral skeleton (right) causing a shift from a coral-dominated ecosystem to an algae-dominated one. (C) Coral life cycle. Corals can reproduce sexually to create larvae that then float and swim until finding a new home, where they settle down and attach to the seafloor. Corals can also reproduce asexually via fragmentation, whereby a piece of an adult colony breaks but then reattaches elsewhere on the seafloor and continues growing to form another colony. Photo credits: Coral images in $\mathrm{A}$ and $\mathrm{B}$ are from the Coral Image Bank (Ocean Agency/Caitlin XL Survey: CC license). Symbiont image in panel $A$ was taken by $T$. LaJeunesse and is reproduced with permission. Polyp image was taken by author H.E.R. Diagram in panel $\mathrm{C}$ is original artwork by Nicola G. Kriefall and is reproduced with permission.

largest coral barrier reef in the United States (15 C.F.R. part 922, subpart P; Pub. L. 101-605, 1990).

- Flower Garden Banks National Marine Sanctuary was established to protect the northernmost living coral reefs on the U.S. continental shelf (56 F.R. 63634, 1991).

- Marianas Trench Marine National Monument protects one of the most diverse coral ecosystems in the Western Pacific and the deepest part of our world's ocean (Proclamation 8335, 2009).

- National Marine Sanctuary of American Samoa (formerly Fagatele Bay National Marine Sanctuary) was designated in response to a proposal from the government of American Samoa, in part to preserve a pristine coral reef terrace ecosystem (51 F.R. 15878, 
1986).

- Virgin Islands Coral Reef National Monument protects coral reefs as essential habitat for sustaining the fragile biological communities in this region (Proclamation 7399, 2001).

- Red Hind Spawning Aggregation Areas west of Puerto Rico are federally managed. All three areas prohibit fishing during the spawning season by implementing area closures from December to February (50 C.F.R. $\S$ 622, 1996). A later amendment to this rule established a marine conservation district east of Puerto Rico, in which fishing activity and anchoring by fishing vessels are banned to protect its coral reef habitat (50 C.F.R. $\S$ $622,1999)$

\section{Which groups manage and enforce MPAs?}

Through related domestic legislation and international trade law (Table 1), several U.S. federal agencies play important roles in the protection of coral reef environments, among their other duties. In 1998, Presidential Executive Order 13089 (Coral Reef Protection) established the United States Coral Reef Task Force (U.S.CRTF), which includes representatives from the Department of the Interior, the Department of Commerce, NOAA, the Environmental Protection Agency (EPA), the Department of Defense, the National Science Foundation, the Department of Transportation, the Department of Agriculture, the Department of State, the Agency for International Development, and the National Aeronautics and Space Administration (Executive Order 13089, 1998). The U.S.CRTF is charged with leading U.S. stewardship of coral reef ecosystems by supporting scientific research, mapping, monitoring, restoration, international cooperation, and the reduction of threats to reefs in coordination with other stakeholder groups.

The groundbreaking Coral Reef Conservation Act of 2000 authorized major contributions to the research, mapping, monitoring, conservation, and management of coral reefs, in large part through the development of a National Action Strategy in consultation with USCRFT and the establishment of NOAA's Coral Reef Conservation Program (CRCP) (Coral Reef Conservation Act of 2000, 2000). The CRCP is one of few federal programs whose direct mission is to address coral reef conservation efforts and the only one with a legislative mandate. In addition to supporting the USCRTF, the CRCP'S multifaceted work involves funding coral research, delivering sound scientific information and tools for management, establishing core partnerships with various stakeholders, and capacity building to help local staff members implement projects that address threats and restore habitats, among other functions. The monumental work of this program relies on federal funds appropriated by Congress. In addition, the U.S. Fish and Wildlife Service manages 10 coral reef National Wildlife Refuges in the Pacific and enforces international trade laws, which regulate the import and export of corals for jewelry or the aquarium trade. The Environmental Protection Agency protects coral reefs by implementing Clean Water
Act programs that maintain water quality in watersheds and coastal zones of coral reef areas. While these functions are important, their pertinence to coral reefs is not congressionally mandated.

A summary of other key domestic policies and the primary agencies responsible for them is shown in Table 1 . There are also several international policies that impact coral reefs, though the U.S. is notably absent from several (see gaps section below). The U.S. is contracting party of the Convention on International Trade in Endangered Species of Wild Fauna and Flora (CITES, 1973), which serves to regulate international trade of animal and plant samples in order to promote conservation and reduce the risk of overexploitation and extinction. All hard coral species (Scleractinia spp.) are listed in the CITES Appendix II, and transport of live specimens or products of these species requires a CITES permit (Resolution Conf. 9.24 Rev. CoP17, 1994).

\section{What's missing: Management and policy gaps in coral reef conservation}

The U.S. stance on ocean policy has varied across administrations. Mostly recently it has shifted from an emphasis on conservation and climate to a focus on economic and security concerns (Executive Order No. 13840, 2018). While the stringency of coral reef conservation has fluctuated, it remains indisputable, as described above, that coral reefs provide substantial economic benefits to many U.S. sectors, in addition to their contributions to biological diversity and ecosystem health. Executive Order 13840, Regarding the Ocean Policy to Advance the Economic, Security, and Environmental Interests of the United States, calls to "facilitate the economic growth of coastal communities and promote ocean industries", among other priorities (Executive Order $13840,2018)$. It is clear from the lengthy list of ecosystem services that preservation of coral reefs is necessary for economic growth and security of many coastal communities.

While there are legal mechanisms (e.g., MPAs) to protect coral reefs under U.S. jurisdiction, gaps often remain in implementation and enforcement. For instance, many MPAs are in remote places where enforcement is difficult, even for countries with substantial resources $[66,67]$. When properly enforced, protection can help alleviate some, though not all, stressors. An evaluation of the ecological performance of MPAs in the U.S. Virgin Islands revealed that coral reefs outside MPAs showed larger declines in ecosystem performance, such as lower density of fish including adult snappers [68]. Notably, the amount of live coral cover decreased both inside and outside MPAs during the study period due to bleaching events and hurricane damage, pointing to the importance of global stressors in driving community structure [68]. Table 2 details additional policy tools to tackle local stressors and provides some examples of gaps in implementation at the municipal, state, and national level.

Key coral reef legislation also requires immediate attention. The Coral Reef Conservation Act of 2000 expired 15 years ago. Reauthorization attempts thus far have either failed or 
remained stagnant in Congress. Most recently, the Restoring Resilient Reefs Act of 2019 was introduced in both the House of Representatives (H.R. 4160) and the Senate (S. 2429) is a bipartisan and bicameral bill to reauthorize and modernize the Coral Reef Conservation Act of 2000. This bill, however, has not yet proceed past the introduction stage. This legislation would a provide a strong base for coordinated national efforts as well as provides $\$ 160$ million of federal funding for the next five years for domestic reef management, conservation, and restoration. Such increases in funding are desperately needed. For instance, the budget for CRCP has held steady around \$27 million per year over the past ten years [69]. This stagnant budget supports work that is becoming increasingly demanding and urgent. Given the vast monetary value that coral reefs represent to the U.S., increasing this and other program budgets would expand their capacity and impact.

On a global geopolitical level, the U.S. has the potential to influence coral reef management in other regions, as well. The USCRTF has active working groups that address specific issues and produce incredibly detailed global, regional, and local recommendations based on science that need to be considered in national policy. For example, $60 \%$ of the aquarium fish trade is imported into the U.S., with almost $90 \%$ originating from Pacific regions [70,71]. While the U.S.AID's program in the Philippines and Indonesia are working to improve problems around both overfishing and destructive fishing (e.g. cyanide or dynamite fishing), the program's limited geographic scope and jurisdiction makes it difficult to coordinate and enforce the larger-scale regional efforts that are needed. To address this, the USCRTF has recommended leveraging work with the Asian Pacific Economic Cooperation (APEC) forum and building a strategic partnership with the South Pacific Region Environmental Program [72].

More broadly, however, the U.S. is not party to some major international conventions that would benefit coral reef ecosystems:

- The United Nations Convention on the Law of the Sea (1982) defines the rights and responsibilities of countries with respect to ocean use in order to maintain peaceful relations between governments (U.N. Convention on the Law of the Sea, 1982). Currently, the U.S. has signed but not ratified the agreement, a move that may jeopardize future claims to ocean resources [73]. Within the agreement, the extent of coral reefs is used to help define the limits of territorial seas, and thus the continued loss of reefs has strong implications for future designations of maritime boundaries.

- The United Nations Convention on Biological Diversity (1992) is a comprehensive agreement between 196 parties dedicated to the conservation and sustainable use of biodiversity. Although President Clinton signed the agreement in 1993 and had support from the Senate Foreign Relations Committee, a Senate vote to ratify it was never held (U.S. Senate Committee on Foreign Relations Activities \& Reports). The U.S. is party to smaller scale agreements, like the Inter-American
Convention for the Protection and Conservation of Sea Turtles and the Specially Protected Areas and Wildlife Protocol.

Saving corals: Restoration, conservation, and research efforts Despite legislative protections against

local impacts, coral reefs have continued to deteriorate mainly due to increasing global temperatures and disease $[6,74]-[76]$. This widespread loss has prompted large-scale restoration efforts, involving government programs (e.g. NOAA Coral Reef Conservation Program), non-governmental organizations (e.g. The Nature Conservancy, SECORE International, etc.), academic institutions, and community groups. The Coral Restoration Consortium, which includes international leaders of multiple coral stakeholder groups, provides a collaborative framework that is crucial for successful coral reef restoration on a global scale (crc. reefresilience.org).

Coral restoration aims to increase the number of healthy adult corals on reefs. However, as corals may reproduce asexually (usually via fragmentation) or sexually, restoration also involves promoting asexual and sexual reproductive processes on reefs to increase coral abundance (Figure $3 \mathrm{C}$ ) $[77,78]$. In the U.S., the largest restoration efforts are in Florida, for the fast-growing staghorn and elkhorn Acropora coral species (the same ones that nearly died out across the Caribbean in 1970s). The Coral Restoration Foundation has led this effort since 2007. To date, the foundation has transplanted over 100,000 coral fragments onto the Florida Reef Tract (www. coralrestoration.org). Coral nurseries in Puerto Rico and the Virgin Islands have also successfully transplanted tens of thousands of coral fragments [79]. Mote Marine Laboratory and Aquarium (www.mote.org), in addition to managing their own underwater coral nursery, has built upon this effort in recent years by developing a method to micro-fragment and fuse typically slower growing corals, thereby speeding up the cultivation process for other species [80].

While increasing asexual reproduction on reefs can help maintain coral populations, only sexual reproduction can generate new genetic diversity. SECORE International (www . secore.org) is leading global coral restoration efforts by regularly producing millions of coral offspring from naturally released eggs and sperm. Once these newborn corals attach to tiles, they are transplanted onto a natural reef, where in time they can mature and contribute to the next generation $[81,82]$. However, restoration success (having transplanted colonies grow and sexually reproduce) is contingent upon the environmental conditions being suitable for corals, since stressors such as poor water quality can significantly reduce fertilization $[83,84]$ and subsequent bleaching can kill transplanted colonies. Increasing the efficiency of coral restoration, e.g. by transplanting coral colonies that are mostly likely to survive and reproduce, in conjunction with improving local environmental conditions will help managers meet the challenges of continued coral population declines [85]. 


\begin{tabular}{|c|c|c|}
\hline Legislation & Agency & Relevance to Coral Reefs \\
\hline $\begin{array}{l}\text { Beaches } \\
\text { Environmental } \\
\text { Assessment and } \\
\text { Coastal Health Act } \\
\text { (33 U.S.C. } § \S 1313 \\
\text { et seq., 2000) }\end{array}$ & EPA & $\begin{array}{l}\text { Amendment to the Clean Water Act; specifically requires the EPA to assess } \\
\text { pathogen levels in recreational waters. Because coral reefs support an active } \\
\text { tourism industry, including recreational snorkeling and SCUBA diving, this Act } \\
\text { supports regular microbiological testing of coral reef waters (thereby reducing } \\
\text { human disease risk). }\end{array}$ \\
\hline $\begin{array}{l}\text { Clean Water Act ( } 33 \\
\text { U.S.C } \S \S 1251 \text { et } \\
\text { seq., 1972) }\end{array}$ & $\begin{array}{l}\text { EPA and the Army Corps } \\
\text { of Engineers }\end{array}$ & $\begin{array}{l}\text { Section } 404 \text { instituted a permit system for regulating any dredge or fill material } \\
\text { that is discharged into U.S. waters, including coral reef areas. The EPA and the } \\
\text { Army Corps of Engineers are responsible for reviewing permit applications and } \\
\text { preventing the discharge of materials on coral reefs when there are practicable } \\
\text { alternatives, or when the negative impacts of released sediments or nutrients are } \\
\text { expected. }\end{array}$ \\
\hline $\begin{array}{l}\text { Coastal } \\
\text { Management } \\
\text { Act }(16 \quad \text { U.S.C. } \\
\S \S 1451 \text { et } \text { seq., } \\
1972)\end{array}$ & NOAA & $\begin{array}{l}\text { Requires the protection of coastal natural resources, including coral reefs. This } \\
\text { Act was passed in response to high human population growth and economic } \\
\text { development in the coastal zone. }\end{array}$ \\
\hline $\begin{array}{l}\text { Endangered } \\
\text { Species Act(16 } \\
\text { U.S.C. §§ } 1531 \text { et } \\
\text { seq., 1973) }\end{array}$ & $\begin{array}{l}\text { U.S. Fish and Wildlife } \\
\text { Service (U.S.FWS) and/or } \\
\text { NOAA Fisheries }\end{array}$ & $\begin{array}{l}\text { Provides federal protection to threatened and endangered species and their } \\
\text { habitats. Actions authorized by the administering agency cannot lead to mortality, } \\
\text { habitat destruction, or removal of the listed species. All protections apply to } \\
\text { endangered species, while protections of threatened species are determined by } \\
\text { the listing agency. Currently, } 22 \text { coral species are listed as threatened and } 3 \text { coral } \\
\text { species are listed as endangered ( } 80 \text { F.R. } 60560,2015 ; 79 \text { F.R. } 53851,2014 ; 71 \\
\text { F.R. } 26852,2006) \text {. Notably, the three endangered species are located outside of } \\
\text { U.S. waters. }\end{array}$ \\
\hline $\begin{array}{l}\text { Magnuson-Stevens } \\
\text { Fishery } \\
\text { Conservation and } \\
\text { Management Act } \\
\text { (reauthorized in } \\
2006)(16 \text { U.S.C. §§ } \\
1801 \text { et seq., 1976) }\end{array}$ & NOAA Fisheries & $\begin{array}{l}\text { The primary law guiding the conservation and sustainable management of U.S. } \\
\text { marine fisheries. The Act also protects fish habitat, which includes tropical coral } \\
\text { reefs in the Western Pacific, Gulf of Mexico, South Atlantic, and Caribbean } \\
\text { regions. }\end{array}$ \\
\hline $\begin{array}{l}\text { Marine Debris } \\
\text { Act(33 U.S.C. } \S \S \\
1951-1958,2006)\end{array}$ & NOAA, U.S. Coast Guard & $\begin{array}{l}\text { Regulates the negative effects of marine debris, defined as "any persistent solid } \\
\text { material that is manufactured or processed," on the marine environment. This } \\
\text { Act established the Marine Debris Program under NOAA, with enforcement by } \\
\text { the U.S. Coast Guard. }\end{array}$ \\
\hline $\begin{array}{l}\text { Marine Protection, } \\
\text { Research, and } \\
\text { Sanctuaries Act (16 } \\
\text { U.S.C. } \S \S 1431 \text { et } \\
\text { seq. and } 33 \text { U.S.C. } \\
\S \S 1401 \text { et seq., } \\
1972)\end{array}$ & $\begin{array}{l}\text { EPA (primary) and Army } \\
\text { Corps of Engineers; } \\
\text { Department of Commerce }\end{array}$ & $\begin{array}{l}\text { Prevents the dumping of material (more than three miles offshore) that would } \\
\text { unreasonably damage the marine environment or ecosystems. Dumping of waste } \\
\text { via land based-pipes (regardless of offshore distance) falls under the regulation } \\
\text { of the Clean Water Act. Section III give the Secretary of Commerce the ability to } \\
\text { designate Marine Sanctuaries in coordination with other agencies. }\end{array}$ \\
\hline $\begin{array}{l}\text { National } \\
\text { Environmental } \\
\text { Policy } \\
(\text { NEPA)(42 U.S.C. } \\
4321 \text { \$§ et seq., } \\
1969)\end{array}$ & $\begin{array}{l}\text { Council on Environmental } \\
\text { Quality } \\
\text { implementation; } \begin{array}{r}\text { oversees } \\
\text { Federal }\end{array} \\
\text { implement NEPA }\end{array}$ & $\begin{array}{l}\text { Requires all federal agencies to prepare Environmental Assessments and/or } \\
\text { Environmental Impact Statements to determine how their proposed actions may } \\
\text { adversely affect the environment, and whether there are reasonable alternatives } \\
\text { to the agency actions. The type of statement required depends on whether } \\
\text { significant environmental effects will be caused by the federal action. For } \\
\text { example, NOAA and the U.S.FWS recently drafted an environmental impact } \\
\text { statement for the Florida Keys National Marine Sanctuary Restoration Blueprint } \\
\text { to help reduce harmful impacts and restore coral reefs, in part by expanding } \\
\text { the geographic boundary of the sanctuary, revising regulations, and updating the } \\
\text { sanctuary management plan ( } 84 \text { F.R. } 45728,2019 \text { ). }\end{array}$ \\
\hline $\begin{array}{l}\text { Rivers and Harbors } \\
\text { Appropriation Act of } \\
1899(33 \text { U.S.C. } \S \S \\
401 \text { et seq., 1899) }\end{array}$ & Army Corps of Engineers & $\begin{array}{l}\text { Requires permits for the creation of structures in navigable waters of the United } \\
\text { States, including bridges, piers, jetties, and breakwaters. The permitting process } \\
\text { is subject to public review, through which any potential harm to beneficial } \\
\text { ecosystems like coral reefs must be assessed. }\end{array}$ \\
\hline $\begin{array}{l}\text { Shore } \quad \text { Protection } \\
\text { Act(100 U.S.C. } \S \S \\
2601-2609,1988)\end{array}$ & $\begin{array}{l}\text { Department } \\
\text { Transportation }\end{array}$ & $\begin{array}{l}\text { Prevents the disposal of municipal and commercial waste in U.S. coastal waters, } \\
\text { including territorial seas. Any vessel that must transport this potentially harmful } \\
\text { material must obtain a permit from the Secretary of Transportation. }\end{array}$ \\
\hline
\end{tabular}




\begin{tabular}{|c|c|c|}
\hline Stressor & Policy Tools & Example Gaps in Implementation \\
\hline $\begin{array}{l}\text { Coastal } \\
\text { development }\end{array}$ & $\begin{array}{l}\text { Stricter regulation of } \\
\text { coastal development and } \\
\text { environmental remediation } \\
{[86]}\end{array}$ & $\begin{array}{l}\text { Many public and private, as well as national and regional, interests are in conflict } \\
\text { with regard to coastal development regulation. For example, in the U.S. Territory } \\
\text { of Guam, the proposed military expansion of Apra Harbor would destroy tens of } \\
\text { acres of coral reefs, some with } 90 \% \text { coral cover, despite significant backlash from } \\
\text { the U.S. Environmental Protection Agency (Commander Navy Region Marianas, } \\
2007) \text {. In general, the U.S. is lacking in environmental regulations and programs } \\
\text { that mitigate impacts from development, with notable issues in the provisions } \\
\text { for environmental impact assessments and statements (EIA/S). These EIA/S are } \\
\text { meant to impartially identify the risks of development in sensitive areas, but can } \\
\text { be fraught with administrative shortcomings and conflicts-of-interest }[87,88] \text {. }\end{array}$ \\
\hline $\begin{array}{l}\text { Insufficient } \\
\text { management } \\
\text { resources }\end{array}$ & $\begin{array}{l}\text { Fees to } \\
\text { conservation [89] }\end{array}$ & $\begin{array}{l}\text { Palau's } 2017 \text { House Bill to introduce the Pristine Paradise Environmental Fee of } \\
\$ 100 \text { for every international departure, included in the airfare price for ease of } \\
\text { management, actually represents a very effective use of this strategy. From each } \\
\text { fee } 47.5 \text { is allocated to the National Treasury, } 10 \text { to the Fisheries Protection Trust, } \\
12.5 \text { to the state treasuries, and } 30 \text { to conservation efforts as a "Green Fee" (RPPL } \\
\text { No. } 10-02) \text {. On the other hand, the } \$ 25 \text { Environmental/Infrastructure Impact } \\
\text { Fee introduced in the U.S. Virgin Islands earmarks nothing for environmental } \\
\text { protection, instead allocating } \% 15 \text { to the V.I. Tourism Advertising Revolving } \\
\text { Fund and } 85 \% \text { to the Territory's General Fund (The Virgin Islands Revenue } \\
\text { Enhancement and Economic Recovery Act of } 2017 \text { ). }\end{array}$ \\
\hline $\begin{array}{l}\text { Increased coastal } \\
\text { nutrient input and } \\
\text { pollution }\end{array}$ & $\begin{array}{l}\text { Improvements to } \\
\text { wastewater management } \\
\text { and infrastructure }[90,91]\end{array}$ & $\begin{array}{l}\text { Approximately half of the sewer lines in the U.S. are past the midpoint of their } \\
\text { life cycle (U.S. EPA, 2002). President Trump proposed infrastructure plans that } \\
\text { included financing for major water infrastructure development (The White House } \\
\text { 2018, 2020). However, President Trump and Democratic congressional leaders } \\
\text { they struggled to identify funding sources and were unable to enact legislation } \\
\text { [92]. On January } 14,2019 \text {, Congress passed the bipartisan Water Infrastructure } \\
\text { and Improvement Act (WIIA) (HR 7279) which amends the Clean Water Act } \\
\text { (CWA) to include the } 2012 \text { Integrated Municipal Stormwater and Wastewater } \\
\text { Planning Approach Framework, providing specific guidelines and a framework } \\
\text { for evaluation, giving a comprehensive voluntary path for municipalities to meet } \\
\text { CWA requirements. }\end{array}$ \\
\hline $\begin{array}{l}\text { Increased coastal } \\
\text { nutrient input and } \\
\text { pollution [cont.] }\end{array}$ & $\begin{array}{lrr}\text { More stringent } & \text { limits } \\
\text { on coastal runoff } & {[86]} \\
\text { with mechanisms } & \text { for } \\
\text { enforcement [93] } & \end{array}$ & $\begin{array}{l}\text { WaterWorks } 2011, \text { a } \$ 740 \text {-million initiative to overhaul Fort Lauderdale's } \\
\text { water, wastewater, and sewer infrastructure successfully reduced levels of } \\
\text { rainfall-induced and groundwater-induced infiltration [94]. However, continuous } \\
\text { sewage line failures have kept the city under scrutiny, as pipe failures released } \\
\text { as many as } 211.6 \text { million gallons of sewage into waterways and streets in a period } \\
\text { of two months. Additional policy actions have been undertaken to address this } \\
\text { gap, though their success remains to be seen: } \\
\text { - In } 2017 \text {, the Florida Legislature codified a Public Notice of Pollution } \\
\text { requirement, which mandates notification of spills of unlawful substances } \\
\text { within } 24 \text { hours, allowing authorities to respond more quickly to incidents } \\
\text { (Chapter } 403.077,2019 \text { ). item Later in } 2017 \text {, the City of Fort Lauderdale } \\
\text { entered a Consent Order with the Florida Department of Environmental } \\
\text { Protection (DEP), agreeing to a number of infrastructure projects and } \\
\text { penalties on future sewer pipe breaks (cite Consent Order). This Consent } \\
\text { Order was enforced recently in early } 2020 \text {, with the State fining the City } \\
\$ 341,500 \text { for its recent sewage spills, along with a civil penalty of } \$ 1.45 \\
\text { million. } \\
\text { - Still, over the past } 16 \text { years, the Florida DEP has struggled to improve codes } \\
\text { for nutrient enrichment of treated wastewater discharge, with no specific } \\
\text { limits and published water quality tables withdrawn twice in the past } 4 \text { years } \\
\text { (Fla. Admin. Code. Rule } 62-302.530 \text { et seq.). }\end{array}$ \\
\hline
\end{tabular}


Despite the benefits restoration can offer at a local scale, the pace of climate change is beyond what most corals can handle. Novel research initiatives exploring the possibilities of assisted evolution in corals and their algal symbionts (Figure $3 \mathrm{~A}$ ), such as selective breeding for heat tolerance, continue to gain traction within science and management communities $[2,95]$. Other efforts to save coral diversity include genetic repositories (where live corals are maintained in aquaria or nurseries) and coral sperm banks through cryopreservation [96].

Recent initiatives have shifted focus from individual species to restoring and protecting entire reef ecosystems. NOAA recently launched Mission: Iconic Reefs, which targets seven reefs in the Florida Keys National Marine Sanctuary for multi-phased, active restoration. This will involve removing invasive species and algae, transplanting both fast and slow-growing coral species, and increasing the population of other beneficial species like sea urchins and Caribbean king crabs. Another unprecedented coral conservation project is the 50 Reefs Initiative (led by The Ocean Agency), which identified reefs likely to survive climate change and repopulate nearby reefs once the climate stabilizes [97]. The approach developed by the 50 Reefs Initiative will allow managers to maximize long term conservation benefits while reducing the risks of devoting limited resources to reefs that are unlikely to withstand projected warming and wave damage from increasingly intense cyclones [97].

\section{Saving corals for the long term: Addressing climate change is our largest policy gap Even with}

these monumental restoration and conservation efforts, the predictions for climate change-driven coral reef loss are grim. The 2018 IPCC report warned that $1.5^{\circ} \mathrm{C}$ increase in global temperatures would correspond to $70-90 \%$ coral reef decline, and a $2{ }^{\circ} \mathrm{C}$ rise could result in the loss of greater than $99 \%$ of reefs [98]. Aggressive international and domestic commitments to reduce greenhouse gas emissions are necessary if coral reefs are to remain functional ecosystems for the benefit of future generations. We, therefore, find it critical to highlight major policies and agreements surrounding greenhouse gas emissions.

The Clean Air Act (42 U.S.C. $\$ 7401,1963)$ and the jurisdiction of the Environmental Protection Agency

- 2007 - Massachusetts vs. EPA, the U.S. Supreme Court ruled that greenhouse gases are pollutants under The Clean Air Act, and should be regulated as such.

- 2010 - Tailoring Rule by EPA establishes emission thresholds and a process for permitting carbon dioxide equivalent emissions for large, stationary emitters like power plants (75 F.R. 31513, 2010).

- 2014 - Utility Air Regulatory Group v. EPA, the U.S. Supreme Court confirmed the jurisdiction of the EPA to regulate greenhouse gas emissions.

- 2015 - Clean Power Plan by EPA established final emission guidelines for states to use in limiting greenhouse gas emissions from power generators (80 F.R. 64661, 2015)

- 2017 - Executive Order 13783 by President Trump prompts the EPA to review the Clean Power Plan as a potential burden to the development of domestic energy resources. The formal process to repeal the plan was initiated that year (Executive Order 13783, 2017).

- 2019 - Affordable Clean Energy Rule by the EPA replaces the Clean Power Plan, stating that the Clean Power Plan overstepped the authority attributed to the EPA under the Clean Air Act (84 F.R. 32520, 2019). Instead, the Affordable Clean Energy Rule places the responsibility of developing standards for $\mathrm{CO} 2$ emissions from existing coal-fired power plants on the states. The rule also points to heat rate improvement measures as the best strategy for reducing emissions, rather than shifting some power generation to renewable energy sources.

The move from the Clean Power Plan (CPP) to the Affordable Clean Energy Rule (ACE) demonstrated a clear shift away from federal regulation of greenhouse gas emissions, and federal promotion of renewable energy use. The CPP was enacted to reduce greenhouse gas emissions from power generation by $32 \%$ compared from 2005 levels by 2030 (U.S. Environmental Protection Agency 2015). In contrast, the ACE does not set limits on carbon emissions, and instead relies on individual states to take the initiative to regulate greenhouse gas emissions from power plants. The emission reductions projected under the CPP totaled around 870 million tons, compared to 11 million tons under the ACE (U.S. Environmental Protection Agency 2015, 2019). Given the sensitivity of corals to bleaching under increasing global temperatures caused by elevated greenhouse gas emissions [98] this change in legislation undermines efforts to protect and restore coral reefs.

The lack U.S. leadership in reducing global greenhouse gas emissions is further demonstrated by its absence from several international agreements:

- 2012 - Kyoto Protocol operationalizes the United Nations Framework Convention on Climate Change by holding industrialized countries to their committed target reductions in greenhouse gas emissions. The U.S. signed but never ratified the agreement. The Doha Amendment to the Kyoto Protocol includes assigned percentage reductions of greenhouse gas emissions by 2020 for individual countries (not including the U.S.), but has not yet entered into force due to the lack of ratification (United Nations, 2012)

- 2015 - The United Nations Framework Convention on Climate Change Paris Agreement strives to limit average global warming to well below $2^{\circ} \mathrm{C}$ relative to preindustrial measurements, with an overall goal to keep the temperature increase to a maximum of $1.5^{\circ} \mathrm{C}$ (United Nations, 2015). The U.S. president announced the U.S. withdrawal from this agreement in 2017, due to the negative impact it would have on the U.S. economy 
(Trump, 2017). However, withdrawing from the Paris Agreement takes four years given the start date of November 4, 2016 (United Nations, 2015), so the earliest possible official withdrawal date is not until November 4, 2020.

Progress towards the global reduction of greenhouse gas emissions continues with the carbon market systems established by other parties to the Paris Agreement. The European Union (EU) Emissions Trading System was the first, and continues to be the largest. The EU system functions by setting a cap on the total amount of specific greenhouse gases emitted, which is lowered over time. Individual companies are then assigned emission allowances for free or purchase allowances via auctions, which they can trade amongst each other [99]. The EU is actively supporting China - the country with the highest annual emissions [100] - in the development of a nationwide carbon emissions trading system [101]. Similar carbon markets already exist in the U.S., but only a small minority of states participate $[102,103]$, limiting realized emission reductions due to the transfer of electricity generation to unregulated sectors [104]

Despite these federal decisions to abstain from strong action against the root cause of climate change, many states have made their own commitments to reduce greenhouse gas emissions consistent with the Paris Agreement. The United States Climate Alliance was formed in response to the impending U.S. withdrawal from the agreement, and includes 24 states and Puerto Rico. The U.S. governors in the alliance have promised to enact policies that reduce emissions $26-28 \%$ below 2005 levels by 2025, track and report progress to the international community, and promote clean energy within their states.

\section{Conclusion}

Coral reefs are one of our planet's most valuable ecosystems [5]. The coastal protection, tourism revenue, biodiversity services, and drug discovery potential of coral reefs are worth trillions of dollars annually [105]. The continued loss of coral reef habitat will represent a significant economic cost to many countries around the world, including the U.S.. The recent actions taken by the U.S. government in national and international policy arenas fall short of an effective strategy to address the greatest global threat to reefs: climate change resulting from increased greenhouse gas emissions. As a country with the second highest annual emissions and the highest cumulative emissions since 1751 [100], the U.S. should take a leading role in the battle against climate change, thereby helping preserve coral reefs for current and future generations. Local management efforts should prioritize the protection of coral reef habitats and strive to mitigate local stressors as much as possible. However, a national and international effort to limit the main source of coral death - increasing global temperatures - is imperative for the future survival of these vibrant marine ecosystems.

\section{Citation}

Rivera, H. E., Chan, A. N. \& Luu, V. Coral reefs are critical for our food supply, tourism, and ocean health. We can protect them from climate change. MIT Science Policy Review 1, 18-33 (2020).

\section{Open Access}

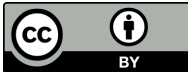

This MIT Science Policy Review article is licensed under a Creative Commons Attribution 4.0 International License, which permits use, sharing, adaptation, distribution and reproduction in any medium or format, as long as you give appropriate credit to the original author(s) and the source, provide a link to the Creative Commons license, and indicate if changes were made. The images or other third party material in this article are included in the article's Creative Commons license, unless indicated otherwise in a credit line to the material. If material is not included in the article's Creative Commons license and your intended use is not permitted by statutory regulation or exceeds the permitted use, you will need to obtain permission directly from the copyright holder. To view a copy of this license, visit http://creativecommons.org/licenses/ by $/ 4.0 /$.

\section{Legislation Cited (in order of appearance in text, then tables)}

- Executive Order 13158, Marine Protected Areas, 65 F.R. 34909 (May 26, 2000). https://www. federalregister.gov/documents/2000/05/ 31/00-13830/marine-protected-areas

- National Marine Sanctuaries Act, 16 U.S.C. §§ 1431 et seq. (1972).

- Antiquities Act, 54 U.S.C. §§ $320301-320303$ (1906).

- Proclamation 8031, Establishment of the Northwestern Hawaiian Islands Marine National Monument, 71 F.R. 36441 (June 15, 2006). https://www . federalregister.gov/documents/2006/ 06/26/06-5725/establishment-of-thenorthwestern-hawaiian-islands-marinenational-monument

- Proclamation 9478, Papahānaumokuākea Marine National Monument Expansion 81 FR 60225 (August 31, 2016). https://www. federalregister. gov/documents/2016/08/31/2016-21138/ papahamacrnaumokuamacrkea-marinenational-monument-expansion

- Proclamation 8336, Establishment of the Pacific Remote Islands Marine National Monument, 74 F.R. 1565 (January 6, 2009). https://www. federalregister.gov/documents/2009/01/ 12/E9-500/establishment-of-the-pacificremote-islands-marine-national-monument

- Florida Keys National Marine Sanctuary, 15 C.F.R. part 922, subpart P; Pub. L. 101-605, Nov. 16, 1990, 104 Stat. 3089 , as amended by Pub. L. 102-587, title II, §§2206, 
2209, Nov. 4, 1992, 106 Stat. 5053 , 5054.

- Flower Garden Banks National Marine Sanctuary, 56 F.R. 63634, Dec. 5, 1991; 60 F.R. 10312, Feb. 24, 1995; 15 C.F.R. part 922, subpart L; Pub. L. 100-627, title II, §205(a)(2), Nov. 7, 1988, 102 Stat. 3217 ; Pub. L. 102-251, title I, §101, Mar. 9, 1992, 106 Stat. 60 ; Pub. L. 104-283, §8, Oct. 11, 1996, 110 Stat. 3366 .

- Proclamation 8335, Establishment of the Marianas Trench Marine National Monument, 74 F.R. 1555 (January 6, 2009). https://www. federalregister.gov/documents/2009/01/ 12/E9-496/establishment-of-the-marianastrench-marine-national-monument

- National Marine Sanctuary of American Samoa (former Fagatele Bay National Marine Sanctuary), 51 F.R. 15878, Apr. 29, 1986; 15 C.F.R. part 922, subpart J; 77 F.R. 43942, July 26, 2012, effective Oct. 15, 2012 (see 77 F.R. 65815).

- Proclamation 7399, Establishment of the Virgin Islands Coral Reef National Monument, 3 C.F.R. 7399 (January 17, 2001). https://www.govinfo.gov/content/ pkg/WCPD-2001-01-22/pdf/WCPD-2001-01-22Pg156.pdf

- Fisheries of the Caribbean, Gulf of Mexico, and South Atlantic; Reef Fish Fishery of Puerto Rico and the U.S. Virgin Islands; Red Hind Spawning Aggregations, 50 C.F.R. § 622 (1996).

- Fisheries of the Caribbean, Gulf of Mexico, and South Atlantic; Coral Reef Resources of Puerto Rico and the U.S. Virgin Islands; Amendment 1, 50 C.F.R. $\S 622$ (1999).

- Executive Order 13089, Coral Reef Protection, 63 F.R. 32701 (June 11, 1998). https://www.govinfo. gov/content/pkg/FR-1998-06-16/pdf/9816161.pdf

- Coral Reef Conservation Act, 16 U.S.C. $\S \S 6401$ et seq. (2000).

- Convention on International Trade in Endangered Species of Wild Fauna and Flora, March 3rd, 1973, 993 U.N.T.S. 243 [hereinafter CITES].

- Criteria for Amendment of Appendices I and II, Resolution Conf. 9.24 (Rev. CoP17), Fort Lauderdale (1994). https://cites.org/sites/default/files/ document/E-Res-09-24-R17.pdf

- Executive Order 13840, Ocean Policy To Advance the Economic, Security, and Environmental Interests of the United States, 83 FR 29431 (June 22, 2018). https: //www. federalregister.gov/documents/2018/ 06/22/2018-13640/ocean-policy-to-advancethe-economic-security-and-environmentalinterests-of-the-united-states

- Restoring Resilient Reefs Act of 2019. 116 U.S.C. §§ H.R. 4160 et seq. (2019).

- Restoring Resilient Reefs Act of 2019. 116 U.S.C. §§ S.
2429 et seq. (2019).

- United Nations Convention on the Law of the Sea, December 10, 1982, 1833 U.N.T.S. 397.

- United Nations Convention on on Biological Diversity, June 5, 1992, 1760 U.N.T.S. 69.

- U.S. Senate Committee on Foreign Relations. 103-20: Convention on Biological Diversity Activities and Reports. https: //www. foreign. senate.gov/treaties/ 103-20.

- The Clean Air Act of 1963, 42 U.S.C. $§ 7401$ (1963).

- Massachusetts et al. v. Environmental Protection Agency et al., 549 U.S. 497 (2007).

- Prevention of Significant Deterioration and Title V Greenhouse Gas Tailoring Rule, 40 C.F.R. §§ 51-52 and 40 C.F.R. §§ 70-71, 75 F.R. 31513 (August 2, 2010). https://www. federalregister.gov/documents/ 2010/06/03/2010-11974/prevention-ofsignificant-deterioration-and-title-vgreenhouse-gas-tailoring-rule

- Utility Air Regulatory Group v. Environmental Protection Agency et al., 573 U.S. 302 (2014).

- Carbon Pollution Emission Guidelines for Existing Stationary Sources: Electric Utility Generating Units (Clean Power Plan), 40 C.F.R. $\S 60,80$ F.R. 64661 (December 22, 2015). https://www. federalregister.gov/documents/2015/10/23/ 2015-22842/carbon-pollution-emissionguidelines-for-existing-stationarysources-electric-utility-generating

- Executive Order 13783, Promoting Energy Independence and Economic Growth, 82 F.R. 16093 (March 28, 2017). https: //www. federalregister.gov/documents/ 2017/03/31/2017-06576/promoting-energyindependence-and-economic-growth

- Repeal of the Clean Power Plan; Emission Guidelines for Greenhouse Gas Emissions From Existing Electric Utility Generating Units; Revisions to Emission Guidelines Implementing Regulations (Affordable Clean Energy Rule), 40 C.F.R. $\S$ 60, 84 F.R. 32520 (September 6, 2019). https://www.federalregister.gov/ documents/2019/07/08/2019-13507/repealof-the-clean-power-plan-emissionguidelines-for-greenhouse-gas-emissionsfrom-existing

- US Environmental Protection Agency (EPA) 2015, Regulatory Impact Analysis for the Clean Power Plan Final Rule https://epa.gov/ttnecasi/docs/ ria/utilities_ria_final-clean-power-planexisting-units_2015-08.pdf

- US Environmental Protection Agency (EPA) 2019, Regulatory Impact Analysis for the Repeal of the Clean Power Plan, and the Emission Guidelines for Greenhouse Gas Emissions from Existing Electric Utility Generating Units https://www.epa.gov/sites/production/ 
files/2019-06/documents/utilities_ria_ final_cpp_repeal_and_ace_2019-06.pdf

- United Nations, Kyoto Protocol to the United Nations Framework Convention on Climate Change, Doha Amendment to the Kyoto Protocol, C.N.718.2012.TREATIES-XXVII.7.c (December 8, 2012).

- United Nations, Paris Agreement, December 12th, 2015, T.I.A.S. No. 16-1104.

- Trump, D.J. (2017). Statement by President Trump on the Paris Climate Accord. https: / / www whitehouse. gov/briefings-statements/statementpresident-trump-paris-climate-accord/

- Beaches Environmental Assessment and Coastal Health Act of 2000, 33 U.S.C. §§ 1313 et seq. (2000).

- Federal Water Pollution Control Act (Clean Water Act), 33 U.S.C. §§ 1251 et seq. (1972).

- Coastal Zone Management Act of 1972, 16 U.S.C. §§ 1451 et seq. (1972).

- The Endangered Species Act of 1973, 16 U.S.C. §§ 1531 et seq. (1973).

- Endangered and Threatened Wildlife and Plants; Final Rule to List the Dusky Sea Snake and Three Foreign Corals Under the Endangered Species Act, 50 C.F.R. $\S \S$ 223-224, 80 F.R. 60560 (November 6, 2015). https: //www. federalregister.gov/documents / 2015/10/07/2015-25484/endangered-andthreatened-wildlife-and-plants-finalrule-to-list-the-dusky-sea-snake-andthree

- Endangered and Threatened Wildlife and Plants: Final Listing Determinations on Proposal to List 66 Reef-Building Coral Species and to Reclassify Elkhorn and Staghorn Corals, 50 C.F.R. $\S 223,79$ F.R. 53851 (October 10, 2014). https://www . federalregister.gov/documents/2014/09/10/ 2014-20814/endangered-and-threatenedwildlife-and-plants-final-listingdeterminations-on-proposal-to-list-66

- Endangered and Threatened Species: Final Listing Determinations for Elkhorn Coral and Staghorn Coral, 50 C.F.R. § 223, 71 F.R. 26852 (June 8, 2006). https: //www.federalregister.gov/documents/2006/ 05/09/06-4321/endangered-and-threatenedspecies-final-listing-determinations-forelkhorn-coral-and-staghorn-coral

- Magnuson-Stevens Fishery Conservation and Management Act (Fishery Conservation and Management Act of 1976), 16 U.S.C. $\S \S 1801$ et seq. (1976).

- Marine Debris Research, Prevention, and Reduction Act (Marine Debris Act), 33 U.S.C. §§ 1951-1958 (2006).

- The Marine Protection, Research, and Sanctuaries Act, 16 U.S.C. §§ 1431 et seq. and 33 U.S.C. §§ 1401 et seq. (1988).

- The National Environmental Policy Act, 42 U.S.C. $\S \S$ 4321 et seq. (1969).

- Notice of Availability of a Draft Environmental Impact Statement for the Florida Keys National Marine Sanctuary Restoration Blueprint; Announcement of Public Meetings, 84 F.R. 45728 (August 30, 2019). https://www.federalregister.gov/ documents/2019/08/30/2019-18783/noticeof-availability-of-a-draft-environmentalimpact-statement-for-the-florida-keysnational

- Rivers and Harbors Appropriation Act of 1899, 33 U.S.C. $\S \S 401$ et seq. (1899) .

- The Shore Protection Act, 100 U.S.C. §§ 2601-2609 (1988)

- Commander Navy Region Marianas. (2007). Kilo Wharf Extension (MILCON P-502), Apra Harbor Naval Complex, Guam, Marianas Islands. Final Environmental Impact Statement, Department of the Navy, U.S. Department of Defense and U.S. Environmental Protection Agency. 322pp.

- RPPL No. 10-02. House Bill No. 10-22-1, HD1, SD2, PD1. Tenth Olbill Era Kelulau First Regular Session. §2706 (January 2017).

- The Virgin Islands Revenue Enhancement and Economic Recovery Act of 2017. 2 Bill No. 32-0005. §1. (2017).

- U.S. Environmental Protection Agency. (2002). Asset Management for Sewer Collection Systems Fact Sheet. https://www3.epa.gov/npdes/pubs/ assetmanagement.pdf

- White House (2018). Legislative Outline for Rebuilding Infrastructure in America. https: //www . whitehouse.gov/wp-content/uploads / 2018/02/INFRASTRUCTURE-211.pdf

- The White House (2020). Historic Investment in America's Infrastructure: A Budget for America's Future. https://www.whitehouse.gov/wpcontent/uploads/2020/02/FY21-Fact-SheetInfrastructure.pdf

- Water Infrastructure and Improvement Act. 115 U.S.C. H.R.7279 (2019)

- Chapter 403.077. (Florida Statutes 2019).

- Florida Department of Environmental Protection Consent Order OGC No. 16-1487 (2017).http: //www.trbas.com/media/media/acrobat/201709/69895557084220-05111531.pdf

- Florida Administrative Code Rule 62-302.530 et seq.

\section{References}

[1] Cinner, J. Coral reef livelihoods. Current Opinion in Environmental Sustainability 7, 65-71 (2014). https: // doi. org/10.1016/j.cosust.2013.11.025. 
[2] Anthony, K. et al. New interventions are needed to save coral reefs. Nature Ecology and Evolution 1, 1420-1422 (2017). https://doi.org/10.1038/s41559-017-0313-5.

[3] Normille, D. El Niño's warmth devastating reefs worldwide. Science 352, 15-16 (2016). https://doi.org/10.1126/ science.352.6281.15.

[4] Hughes, T. P. et al. Global warming transforms coral reef assemblages. Nature 556, 492-496 (2018). https://doi. org/10.1038/s41586-018-0041-2.

[5] de Groot, R. et al. Global estimates of the value of ecosystems and their services in monetary units. Ecosystem Services 1, 50-61 (2012). https://doi.org/10.1016/j.ecoser. 2012.07 .005$.

[6] Hughes, T. P. et al. Global warming and recurrent mass bleaching of corals. Nature 543, 373-377 (2017). https: //doi.org/10.1038/nature21707.

[7] Thompson, J. R., Rivera, H. E., Closek, C. J. \& Medina, M. Microbes in the coral holobiont: Partners through evolution, development, and ecological interactions. Frontiers in Cellular and Infection Microbiology 4, 1-20 (2014). https://doi. org/10.3389/fcimb.2014.00176.

[8] Schmidt, T. S., Raes, J. \& Bork, P. The Human Gut Microbiome: From Association to Modulation. Cell 172, 1198-1215 (2018). https://doi.org/10.1016/j.cell.2018.02.044.

[9] Woodhead, A. J., Hicks, C. C., Norström, A. V., Williams, G. J. \& Graham, N. A. Coral reef ecosystem services in the Anthropocene. Functional Ecology 33, 1023-1034 (2019). https://doi.org/10.1111/1365-2435.13331.

[10] Beck, M. W. et al. The global flood protection savings provided by coral reefs. Nature Communications 9 (2018). https:// doi.org/10.1038/s41467-018-04568-z.

[11] Inc., W. C. U.S. airports, seaports, \& border crossings (2020).

[12] Smith, S. V. Coral-reef area and the contributions of reefs to processes and resources of the world's oceans. Nature 273, 225-226 (1978).

[13] Fisher, R. et al. Species richness on coral reefs and the pursuit of convergent global estimates. Current Biology 25, 500-505 (2015). https://doi.org/10.1016/j.cub. 2014.12 .022$.

[14] Bruckner, A. Life-saving products from coral reefs. Issues in Science and Technology 18 (Spring 2002).

[15] Schmidtko, A., Lötsch, J., Freynhagen, R. \& Geisslinger, G. Ziconotide for treatment of severe chronic pain. New Drug Class 375, 1569-1577 (2010). https: // doi . org/10. 1016/S0140-6736 (10)60354-6.

[16] Lopez, Y., Cepas, V. \& Soto, S. M. The marine ecosystem as a source of antibiotics. In Rampelotto, P. H. \& Trincone, A. (eds.) Grand Challenges in Marine Biotechnology, chap. 1, 3-48 (Springer International Publishing, 2018). https:// doi.org/10.1007/978-3-319-69075-9_9.

[17] Green, D. W., Ben-Nissan, B., Yoon, K. S., Milthorpe, B. \& Jung, H. S. Natural and Synthetic Coral Biomineralization for Human Bone Revitalization. Trends in Biotechnology 35, 43-54 (2017). https://doi.org/10.1016/j.tibtech.2016.10.003.

[18] Altmann, K. H. Drugs from the oceans: Marine natural products as leads for drug discovery. Chimia 71, 646-651 (2017). https://doi.org/10.2533/chimia.2017.646.

[19] Jiménez, C. Marine Natural Products in Medicinal Chemistry. ACS Medicinal Chemistry Letters 9, 959-961 (2018). https: //doi.org/10.1021/acsmedchemlett.8b00368.

[20] FAO. The state of the world fisheries and aquaculture 2018 Meeting the sustainable development goals. Tech. Rep., United Nations, Rome, Italy (2018)

[21] Brander, L. \& Van Beukering, P. The Total Economic Value of U.S. Coral Reefs: A Review of the Literature. Tech. Rep., NOAA Coral Reef Conservation Program, Silver Spring, MD (2013). URL https://www.ncei.noaa. gov/data/oceans/coris/library/NOAA/CRCP/other/ other_crcp_publications/TEV_US_Coral_Reefs_ Literature_Review_2013.pdf.
[22] Authority, G. B. R. M. P. Great Barrier Reef Outlook Report 2019. Tech. Rep., Great Barrier Reef Marine Park Authority, Townsville, Australia (2019). URL http://elibrary.gbrmpa.gov.au/jspui/bitstream/ 11017/3474/10/Outlook-Report-2019-FINAL.pdf.

[23] Spalding, M. et al. Mapping the global value and distribution of coral reef tourism. Marine Policy 82, 104-113 (2017). https : //doi.org/10.1016/j.marpol.2017.05.014.

[24] Hoegh-Guldberg, O., Pendleton, L. \& Kaup, A. People and the changing nature of coral reefs. Regional Studies in Marine Science 30, 100699 (2019). https://doi.org/10.1016/ j.rsma.2019.100699.

[25] Glynn, P. W. Coral reef bleaching: Ecological perspectives. Coral Reefs 12, 1-17 (1993). https://doi.org/10.1007/ BE 00303779 .

[26] Davy, S. K., Allemand, D. \& Weis, V. M. Cell Biology of Cnidarian-Dinoflagellate Symbiosis. Microbiology and Molecular Biology Reviews 76, 229-261 (2012). https:// doi.org/10.1128/MMBR.05014-11.

[27] Heron, S. F., Maynard, J. A., van Hooidonk, R. \& Eakin, C. M. Warming trends and bleaching stress of the world's coral reefs 1985-2012. Scientific Reports 6, 38402 (2016). https:// doi.org/10.1038/srep38402.

[28] Sully, S., Burkepile, D. E., Donovan, M. K., Hodgson, G. \& van Woesik, R. A global analysis of coral bleaching over the past two decades. Nature Communications 10, 1264 (2019). https://doi.org/10.1038/s41467-019-09238-2.

[29] Barkley, H. C. et al. Repeat bleaching of a central Pacific coral reef over the past six decades (1960-2016). Nature Biology Communications 1, 177 (2018). https: //doi.org/ $10.1038 / \mathrm{s} 42003-018-0183-7$.

[30] Halpern, B. S. et al. An index to assess the health and benefits of the global ocean. Nature 488, 615-620 (2012). https: //doi.org/10.1038/nature11397.

[31] Bikes, S. N. Australia's Great Barrier Reef suffers most extensive coral bleaching (2020). URL https://news. trust.org/item/20200604055724-nbjg4/.

[32] Hughes, T. P. et al. Climate change, human impacts, and the resilience of coral reefs. Science 301, 929-33 (2003). URL http://www.ncbi.nlm.nih.gov/pubmed/12920289. https://doi.org/10.1126/science.1085046.

[33] Hughes, T. P. et al. Spatial and temporal patterns of mass bleaching of corals in the Anthropocene. Science 359, 80-83 (2018). URL www.sciencemag.org/content/359/6371/ 80/suppl/DC1. https://doi.org/10.1126/science. aan8048.

[34] Green, E. P. \& Bruckner, A. W. The significance of coral disease epizootiology for coral reef conservation. Biological Conservation 96, 347-361. https://dx.doi.org/10. 1016/S0006-3207(00)00073-2.

[35] Gladfelter, W. B. White-band disease in Acropora palmata: Implications for the sturucture and growth of shallow reefs. Bulletin of Marine Science 32, 639-643 (1982).

[36] Walton, C. J., Hayes, N. K. \& Gilliam, D. S. Impacts of a regional, multi-year, multi-species coral disease outbreak in Southeast Florida. Frontiers in Marine Science 5, 1-14 (2018). https://doi.org/10.3389/fmars.2018.00323.

[37] Leggat, W. P. et al. Rapid Coral Decay Is Associated with Marine Heatwave Mortality Events on Reefs. Current Biology 29, 2723-2730.e4 (2019). https://doi.org/10.1016/j. cub.2019.06.077.

[38] Redding, J. E. et al. Link between sewage-derived nitrogen pollution and coral disease severity in Guam. Marine Pollution Bulletin 73, 57-63 (2013). https://doi.org/10.1016/j. marpolbul.2013.06.002.

[39] Miller, M. W. et al. Detecting sedimentation impacts to coral reefs resulting from dredging the Port of Miami, Florida USA. PeerJ 2016, 1-19 (2016). https://doi.org/10.7717/ peerj.2711. 
[40] Cunning, R., Silverstein, R. N., Barnes, B. B. \& Baker, A. C. Extensive coral mortality and critical habitat loss following dredging and their association with remotely-sensed sediment plumes. Marine Pollution Bulletin 145, 185-199 (2019). https : //doi.org/10.1016/j.marpolbul.2019.05.027.

[41] Vega Thurber, R. L. et al. Chronic nutrient enrichment increases prevalence and severity of coral disease and bleaching. Global change biology 20, 544-54 (2014). https://doi.org/10. $1111 / \mathrm{gcb} .12450$.

[42] Maynard, J. et al. Projections of climate conditions that increase coral disease susceptibility and pathogen abundance and virulence. Nature Climate Change 5, 688-694 (2015). https://doi.org/10.1038/nclimate2625.

[43] Doney, S. C., Fabry, V. J., Feely, R. A. \& Kleypas, J. A. Ocean acidification: The other $\mathrm{CO} 2$ problem. Annual Review of Marine Science 1, 169-192 (2009). https://doi.org/10.1146/ annurev marine.010908.163834.

[44] Cyronak, T., Schulz, K. G., Santos, I. R. \& Eyre, B. D. Enhanced acidification of global coral reefs driven by regional biogeochemical feedbacks. Geophysical Prospecting 41, 6413-6419 (2014). https://doi.org/10.1002/ 2014GL061184. Received.

[45] Pandolfi, J. M., Connolly, S. R., Marshall, D. J. \& Cohen, A. L. Projecting coral reef futures under global warming and ocean acidification. Science 333, 418-22 (2011). https://doi. org/10.1126/science.1204794.

[46] Feely, R. A. et al. Impact of anthropogenic $\mathrm{CO} 2$ on the $\mathrm{CaCO} 3$ system in the oceans. Science 305, 362-366 (2004). https: //doi.org/10.1126/science.1097329.

[47] DeCarlo, T. M. et al. Coral macrobioerosion is accelerated by ocean acidification and nutrients. Geology 43, 7-10 (2014). https://doi.org/10.1130/G36147.1.

[48] Kurihara, H. Effects of CO2-driven ocean acidification on the early developmental stages of invertebrates. Marine Ecology Progress Series 373, 275-284 (2008). https://doi.org/ $10.3354 / \mathrm{meps} 07802$.

[49] Schunter, C. et al. An interplay between plasticity and parental phenotype determines impacts of ocean acidification on a reef fish. Nature Ecology and Evolution 2, 334-342 (2018). https: //doi.org/10.1038/s41559-017-0428-8.

[50] Davies, S. W., Marchetti, A., Ries, J. B. \& Castillo, K. D. Thermal and pCO2 stress elicit divergent transcriptomic responses in a resilient coral. Frontiers in Marine Science 3, 112 (2016). https://doi.org/10.3389/fmars.2016.00112.

[51] Foster, T. et al. Dredging and port construction around coral reefs. Tech. Rep., United Nations Environmental Program - PIANC (2010). URL https://www. unepwcmc.org/system/dataset_file_fields/files/000/ 000/099/original/2010_PIANC_Dredging_and_port_ construction_around_coral_reefs_Report_1082010_EINAL_VERSION_LowRes.pdf?1398441422.

[52] Valadez-Rocha, V. \& Ortiz-Lozano, L. Spatial and temporal effects of port facilities expansion on the surface area of shallow coral reefs. Environmental Management 52, 250-260 (2013). https://doi.org/10.1007/s00267-013-0098-5.

[53] Mora, C., Graham, N. A. \& Nyström, M. Ecological limitations to the resilience of coral reefs. Coral Reefs 35, 1271-1280 (2016). https://doi.org/10.1007/s00338-016-1479-z.

[54] Madin, E. M. P. Land reclamation: Halt reef destruction in South China Sea. Nature 524, 291 (2015). https://doi.org/10. 1038/524291a.

[55] McCook, L. J. Macroalgae, nutrients and phase shifts on coral reefs: scientific issues and management consequences for the Great Barrier Reef. Coral Reefs 18, 357-367 (1999). https: //doi.org/10.1007/s003380050213.

[56] Hughes, T. P. et al. Phase shifts, herbivory, and the resilience of coral reefs to climate change. Current Biology 17, 360-365 (2007). https://doi.org/10.1016/j.cub. 2006.12 .049 .
[57] Stamski, R. E. \& Field, M. E. Characterization of sediment trapped by macroalgae on a Hawaiian reef flat. Estuarine, Coastal and Shelf Science 66, 211-216 (2006). https:// doi.org/10.1016/j.ecss.2005.08.010.

[58] Yang, X. et al. Treated Wastewater Changes the Export of Dissolved Inorganic Carbon and Its Isotopic Composition and Leads to Acidification in Coastal Oceans. Environmental Science and Technology 52, 5590-5599 (2018). https:// doi.org/10.1021/acs.est.8b00273.

[59] Burkepile, D. E. \& Hay, M. E. Impact of Herbivore Identity on Algal Succession and Coral Growth on a Caribbean Reef. Plos One 5, e8963 (2010). https://doi.org/10.1371/ journal.pone.0008963.

[60] Burkepile, D. E. \& Hay, M. E. Nutrient versus herbivore control of macroalgal community development and coral growth on a Caribbean reef. Marine Ecology Progress Series 389, 71-84 (2009). https://doi.org/10.3354/meps08142.

[61] Mumby, P. J. Stratifying herbivore fisheries by habitat to avoid ecosystem overfishing of coral reefs. Journal of Time Series Analysis 35, 266-278 (2014). https: //doi.org/10.1111/ faf. 12078.

[62] Luckhurst, B. E. \& Farrell, S. O. Rapid Recovery of Parrotfish (Scaridae) and Surgeonfish (Acanthuridae) Populations Following the Fish Pot Ban in Bermuda. Proceedings of 66th Gulf and Caribbean Fisheries Institute 301-306 (2013).

[63] Katikiro, R. E. \& Mahenge, J. J. Fishers' Perceptions of the Recurrence of Dynamite-Fishing Practices on the Coast of Tanzania. Frontiers in Marine Science 3, 233 (2016). https : //doi.org/10.3389/fmars.2016.00233.

[64] Pet-Soede, L. \& Erdmann, M. An overview and comparison of destructive fishing practices in Indonesia. SPC Live Reef Fish Information Bulletin 28-36 (1998). URL http://www.spc.int/DigitalLibrary/Doc/FAME/ InfoBull/LRF/4/LRF4 \{_\}28 \{_\}Pet-Soede.pdf.

[65] Selig, E. R. \& Bruno, J. F. A global analysis of the effectiveness of marine protected areas in preventing coral loss. PLOS ONE 5, e9278 (2010). https://doi.org/10.1371/journal. pone. 0009278 .

[66] Richardson, M. Protecting America's Pacific Marine Monuments: A Review of Threats and Law Enforcement Issues. Tech. Rep., Marine Conservation Institute (2012).

[67] Edgar, G. J. et al. Global conservation outcomes depend on marine protected areas with five key features. Nature 506, 216-220 (2014). https://doi.org/10.1038/ nature13022.

[68] Pittman, S. J. et al. Marine Protected Areas of the US Virgin Islands: Ecological Performance Report. NOAA Technical Memorandum NOS NCCOS 187 (2014). URL https://www.ncei.noaa.gov/data/oceans/coris/ library/NOAA/CRCP/project/538/MPAs_Working_ Final_tagged_LQ.pdf.

[69] NOAA. FY10-FY20 Budget Blue Book Summary - NOAA. Tech. Rep., NOAA, Washinton DC, USA.

[70] Rhyne, A. L. et al. Revealing the Appetite of the Marine Aquarium Fish Trade: The Volume and Biodiversity of Fish Imported into the United States. PLOS ONE 7, e35808 (2012). https://doi.org/10.1371/journal.pone.0035808.

[71] Rhyne, A. L., Tlusty, M. F., Szczebak, J. T. \& Holmberg, R. J. Expanding our understanding of the trade in marine aquarium animals. PeerJ 2017, e2949 (2017). https: / / doi.org/10. $7717 /$ peerj. 2949.

[72] NOAA. South East Asia Subgroup Report to the U.S. Coral Reef Task Force. Tech. Rep. URL https://www. coralreef.gov/international/mainb.html.

[73] Gavrilov, V., Dremliuga, R. \& Nurimbetov, R. Article 234 of the 1982 United Nations Convention on the law of the sea and reduction of ice cover in the Arctic Ocean. Marine Policy 106, 103518 (2019). https://doi.org/10.1016/j.marpol. 2019.103518. 
[74] Precht, W. F., Gintert, B. E., Robbart, M. L., Fura, R. \& Van Woesik, R. Unprecedented disease-related coral mortality in southeastern Florida. Scientific Reports 6, 31374 (2016). https://doi.org/10.1038/srep31374.

[75] Van Woesik, R. \& Randall, C. J. Coral disease hotspots in the Caribbean. Ecosphere 8, e01814 (2017). https: // doi .org/ 10.1002 /ecs2.1814.

[76] Muller, E. M., Bartels, E. \& Baums, I. B. Bleaching causes loss of disease resistance within the threatened coral species Acropora cervicornis. elife 7, e35066 (2018). URL https: //doi.org/10.7554/eLife.35066.001. https://doi. org/10.7554/eLife.35066.001.

[77] Highsmith, R. C. Reproduction by fragmentation in corals. Marine Ecology Progress Series 7, 207-226 (1982).

[78] Richmond, R. H. \& Hunter, C. L. Reproduction and recruitment of corals: comparisons among the Caribbean, the Tropical Pacific, and the Red Sea. Marine Ecology Progress Series 60, 185-203 (1990).

[79] Moulding, A. L., Griffin, S. P., Nemeth, M. I. \& Ray, E. C. Caribbean Acropora Outplanting in U.S. Jurisdiction: 1993-2017. NOAA Technical Memorandum NMFS-SER-10 (2020). https://doi.org/10.25923/n4tx-1a30.

[80] Forsman, Z. H., Page, C. A., Toonen, R. J. \& Vaughan, D. Growing coral larger and faster: micro-colony-fusion as a strategy for accelerating coral cover. PeerJ 3, e1313 (2015). https://doi.org/10.7717/peerj.1313.

[81] Chamberland, V. F. et al. Restoration of critically endangered elkhorn coral (Acropora palmata) populations using larvae reared from wild-caught gametes. Global Ecology and Conservation 4, 526-537 (2015). https://doi.org/10. $1016 / j$.gecco.2015.10.005.

[82] Chamberland, V. F. et al. Four-year-old Caribbean Acropora colonies reared from field-collected gametes are sexually mature. Bulletin of Marine Science 92, 263-264 (2016). https://doi.org/10.5343/bms.2015.1074.

[83] Harrison, P. L. \& Ward, S. Elevated levels of nitrogen and phosphorus reduce fertilisation success of gametes from scleractinian reef corals. Marine Biology 139, 1057-1068 (2001). https://doi.org/10.1007/s002270100668.

[84] Hédouin, L. \& Gates, R. D. Assessing fertilization success of the coral Montipora capitata under copper exposure: Does the night of spawning matter? Marine Pollution Bulletin 66, 221-224 (2013). https://doi.org/10.1016/ j.marpolbul.2012.11.020.

[85] Baums, I. B. et al. Considerations for maximizing the adaptive potential of restored coral populations in the western Atlantic. Ecological Applications 29, 1-23 (2019). https : / / doi . org/ 10.1002/eap.1978.

[86] D'Angelo, C. \& Wiedenmann, J. Impacts of nutrient enrichment on coral reefs: New perspectives and implications for coastal management and reef survival. Current Opinion in Environmental Sustainability 7, 82-93 (2014). https: // doi. org/10.1016/j.cosust.2013.11.029.

[87] Singh, G. G. et al. Scientific shortcomings in environmental impact statements internationally. People and Nature 2, 369-379 (2020). https://doi.org/10.1002/pan3. 10081.

[88] Hollick, M. Environmental Impact Assessment: An International Evaluation. Environmental Management 10, 157-178 (1986). https://doi.org/10.1007/BF01867355.

[89] Edwards, P. E. Sustainable financing for ocean and coastal management in Jamaica: The potential for revenues from tourist user fees. Marine Policy 33, 376-385 (2009). https : / doi. org/10.1016/j.marpol.2008.08.005.

[90] Lapointe, B. E. et al. Macroalgal blooms on southeast Florida coral reefs: I. Nutrient stoichiometry of the invasive green alga Codium isthmocladum in the wider Caribbean indicates nutrient enrichment. Harmful Algae 4, 1092-1105 (2005). https:// doi.org/10.1016/j.hal.2005.06.004.
[91] Wear, S. L. \& Thurber, R. V. Sewage pollution: Mitigation is key for coral reef stewardship. Annals of the New York Academy of Sciences 1355, 15-30 (2015). https : / / doi.org/10.1111/ nyas. 12785.

[92] Naylor, B. Trump and democrats agree to $\$ 2$ trillion infrastructure package (2019). https://www.npr.org/ 2019/04/30/718677236/trump-and-democratsagree-on-2-trillion-for-infrastructure-butnot-on-how-to-pay.

[93] Helland, E. The enforcement of pollution control laws: Inspections, violations, and self-reporting. Review of Economics and Statistics 80, 1410153 (1998). https: / / doi . $\mathrm{org} / 10.1162 / 003465398557249$.

[94] Schwarz, W. Implementing a successful I\&I removal program in fort lauderdale, FL. In Pipelines 2009: Infrastructure's Hidden Assets - Proceedings of the Pipelines 2009 Conference, vol. 360, 731-740 (2009). https://doi.org/10.1061/ $41069(360) 68$.

[95] van Oppen, M. J. H., Oliver, J. K., Putnam, H. M. \& Gates, R. D. Building coral reef resilience through assisted evolution. Proceedings of the National Academy of Sciences 112 2307-2313 (2015). https://doi.org/10.1073/pnas. 1422301112 .

[96] Hagedorn, M. et al. Producing Coral Offspring with Cryopreserved Sperm: A Tool for Coral Reef Restoration. Scientific Reports 7, 1-9 (2017). https://doi.org/10. $1038 / s 41598-017-14644-x$.

[97] Beyer, H. L. et al. Risk-sensitive planning for conserving coral reefs under rapid climate change. Conservation Letters $\mathbf{1 1}$ 1-10 (2018). https://doi.org/10.1111/conl.12587.

[98] Hoegh-Guldberg, O. et al. Impacts of 1.5C of Global Warming on Natural and Human Systems (2018).

[99] EU Emissions Trading System (EU ETS) | Climate Action. URL https://ec.europa.eu/clima/policies/ets $\{$ \}en.

[100] Ritchie, H. \& Roser, M. Co and greenhouse gas emissions. Our World in Data (2017). URL https: / / ourworldindata. org/co2-and-other-greenhouse-gas-emissions.

[101] EUCHINA-ETS: EU-China Emission Trading System.

[102] The Regional Greenhouse Gas Initiative: an initiative of the New England and Mid-Atlantic States of the U.S. URL https:// www.rggi.org/.

[103] California Air Resources Board: California Cap-and-Trade Program. URL https://ww2.arb.ca.gov/our-work/ programs/cap-and-trade-program.

[104] Fell, H. \& Maniloff, P. Leakage in regional environmental policy: The case of the regional greenhouse gas initiative. Journal of Environmental Economics and Management 87, 1-23 (2018). https://doi.org/10.1016/j.jeem.2017.10.007.

[105] Costanza, R. et al. Changes in the global value of ecosystem services. Global Environmental Change 26, 152-158 (2014). https://doi.org/10.1016/j. gloenvcha.2014.04.002. 